\title{
Создание и применение нетрадиционных оптических материалов с повышенной радиационной устойчивостью
}

\author{
М.В. Агринский, В.М. Волынкин, В.В. Старцев \\ Акиионерное общество «Оптико-механическое конструкторское бюро «АСТРОН», \\ Московская область, г. Лыткарино, 140080, ул. Парковая, 1 \\ тел./факс: +7 (495) 941-6272, эл. почта: v@
}

DOI 10.34077/RCSP2019-89

При проектировании объективов с высоким качеством формируемого оптического изображения для обеспечения надежного функционирования их в условиях облучения ионизирующим излучением выбирают оптические материалы из каталога радиационно-стойких стекол. Известно [1], что обычные оптические стекла сохраняют приемлемую пропускающую способность только при экспозиционных дозах (радиационных нагрузках), в среднем не превышающих $10^{4} \mathrm{P}$. Кроме обычных оптических стекол, существуют радиационно-стойкие оптические стекла, т. е. стекла, способные сохранять высокую пропускающую способность в условиях их облучения ионизирующим излучением и могут функционировать в радиационных полях с экспозиционными дозами, превышающими $10^{4} \mathrm{P}$. В зависимости от предельных радиационных нагрузок радиационностойкие стекла отечественного производства представлены в двух каталогах. Первый каталог насчитывает чуть более 60 марок радиационно-стойких стекол, которые называют оптическими стеклами серии 100. Второй каталог радиационно-стойких стекол включает в себя 10 марок стекол, 8 из которых обладают повышенной радиационно-оптической устойчивостью к $\gamma$-излучению дозами, превышающими $10^{5}$ Р. Эти стекла называют оптическими стеклами серий 200 и Н [2]. Каталог аналогичных стекол, производимых фирмой Schott, включает 6 марок стекол, которые недоступны или могут поставляться заказчикам только по предварительным заказам.

Для проектирования объективов апохроматов были созданы нетрадиционные оптические материалы:

оптическая среда (гелеобразная) с радиационной стойкостью до $10^{6} \mathrm{P}$ в области прозрачности от 0 , 3 до 2,5 мкм с показателем преломления $\mathrm{n}_{\mathrm{e}}=1,4120$, работающая в интервале температур от минус $50^{\circ} \mathrm{C}$ до $+150^{\circ} \mathrm{C}$;

оптическая среда (термопластичная) с радиационной стойкостью до $10^{8} \mathrm{P}$ в области прозрачности от 0,4 до 2,0 мкм с показателем преломления $\mathrm{n}_{\mathrm{e}}=1,5897$, работающая в интервале температур от минус $60^{\circ} \mathrm{C}$ до $+85^{\circ} \mathrm{C}$.

Проведен расчет и макетирование базового объектива апохромата. Параксиальные характеристики и конструктивные параметры рассчитанной системы следующие: $\mathrm{F}^{\prime}=50$ мм, $2 \mathrm{w}=8 \mathrm{O}, \mathrm{F} / \#=2,5$. На рисунке 1 представлено схемное изображение объектива.

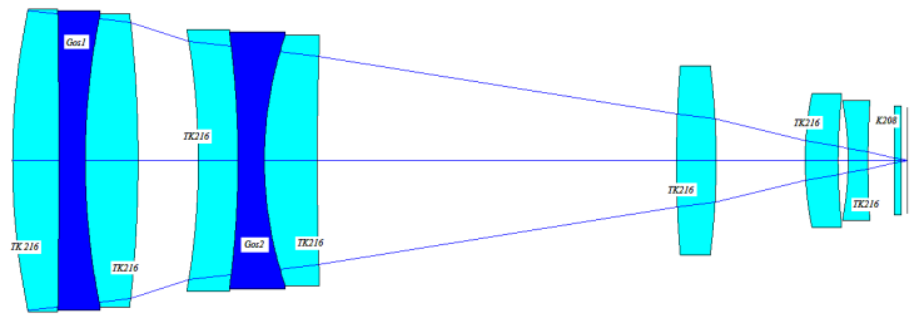

Рисунок 1 - схемное изображение объектива, где в голубой цвет окрашены стекла серии 200 , а в синий - созданные среды

\section{Литература}

[1] В.И. Арбузов. Основы радиационного оптического материаловедения. Учебное пособие. СПб: СПбГУИТМО. 2008. - 284 стр.

[2] ОСТ 3-3677-82. Стекло оптическое серий 200 и Н. 